\title{
THE THORACIC SURGERY FOUNDATION FOR RESEARCH AND EDUCATION
}

\section{RESEARCH AWARD RECIPIENTS}

The Foundation is proud to support the following new scholars for 2000 :

Paul M. Kirshbom, MD

Children's Hospital of Pennsylvania

TSFRE Research Grant

Raja S. Mahidhara, MD

University of Pittsburgh

TSFRE Research Fellowship

Steffen Pfeiffer, MD

Vanderbilt University Medical Center

TSFRE Research Fellowship

\section{Lynne A. Skaryak, MD}

University of Massachusetts Medical Center

Nina S. Braunwald Research Fellowship
Wilson Y. Szeto, MD

Hospital of the University of Pennsylvania

TSFRE Research Fellowship

Mohan Thanikachalam, MD

University of Miami

TSFRE Research Fellowship

Thomas K. Waddell, PhD, MD

Toronto General Hospital and the University of Toronto TSFRE Research Grant 